\title{
BERBAGAI BENTUK PEMANFAATAN \\ BANGUNAN INDIS DI KOTA MALANG: \\ Pemikiran Awal Tentang Pengelolaan BCB
}

\author{
Muhammad Chawari \\ (Balai Arkeologi Yogyakarta)
}

\begin{abstract}
The use of archaeological resources (BCB) in Indonesia is regulated in Law No. 51992 on Cultural Property and Indonesian Government Regulation No. 101993 on the implementation of the Law no. 51992. According to these regulations, cultural property may be used for many purposes such as religious, social, tourism, education, science, and cultural purposes. This paper illustrates the use of some colonial buildings in the City of Malang which is not only in accord with the regulations but also added economical value.

the building could also be associated with economical value. There are some examples in Malang showing the use of $\mathrm{BCB}$ based on its economical value, but the implementation tended to be individualistic and hasn't reached international level yet. The practical activities include: Festival Malang or Malang Old Festival; producing t-shirts and sticker with pictures of indis buildings; displaying pictures of indis buildings in restaurants, hotels, and stores, and also making various forms of old advertisement by one of the bakery in Malang.
\end{abstract}

Key words: archaeological resource, Indis, and City of Malang.

\section{PENGANTAR}

Daerah Malang pertama kali dikuasai pihak asing sekitar tahun 1767. Sejak saat itu, pengaruh asing mulai berperan aktif dalam berbagai segi kehidupan masyarakat Malang. Salah satu pengaruh yang jelas terlihat adalah munculnya berbagai bangunan bergaya kolonial dengan bentuk dan fungsi yang sangat beragam. Setidaknya hal ini diketahui dari hasil penelitian yang dilakukan pada tahun 2007. Dari hasil penelitian itu dapat diketahui bahwa di Kota Malang paling tidak terdapat sekitar 208 bangunan bergaya kolonial yang terbagi dalam 15 fungsi yang berbeda (Chawari, 2007: 11).

Hasil penelitian tahun 2007 ditindaklanjuti dengan penelitian tahun 2008 yang merupakan penelitian terapan untuk pengelolaan sumberdaya arkeologi. Secara umum penelitian ini bertujuan terutama untuk mengetahui 
cara-cara pemanfaatan bangunan kolonial atau indis di Kota Malang, selanjutnya memberikan arahan pemanfaatan yang lebih sesuai dengan UU No. 5 Tahun 1992 tentang BCB. Untuk itu, beberapa altematif kegiatan pemanfaatan yang dapat dilakukan akan dibahas dalam tulisan ini.

\section{PROSES PENGUMPULAN DATA}

Untuk mengumpulkan informasi yang dibutuhkan dilakukan observasi terhadap bangunan-bangunan indis yang diteliti. Selain itu, dilakukan wawancara terhadap pemilik bangunan atau ahli warisnya, para pengelola bangunan maupun nara sumber lain yang mengetahui tentang bangunan-bangunan kuna tersebut. Wawancara juga dilakukan terhadap pihak-pihak yang berkedudukan sebagai penentu kebijakan, dan mereka yang peduli terhadap keberadaan dan kondisi bangunan indis dewasa ini agar diperoleh data mengenai perspektif mereka.

Observasi atau pengamatan dilakukan terhadap beberapa bangunan indis yang dijadikan contoh atau sample. Kegiatan ini diperlukan untuk mendapatkan data yang lebih akurat serta gambaran yang lebih tepat tentang cara-cara pemanfaatan bangunan-bangunan tersebut. Termasuk dalam kegiatan observasi, dilakukan pula identifikasi dan dokumentasi berbagai kegiatan pemanfaatan yang berhubungan (baik secara langsung maupun tidak langsung) dengan keberadaan bangunan indis di Kota Malang, di antaranya adalah acara Festival Malang Kembali.

Untuk memulai pengumpulan data melalui wawancara, hal pertama yang dilakukan adalah menentukan dan memilih responden. Pemilihan responden didasarkan pada peran dan tugas mereka terkait dengan keberadaan bangunan indis di Kota Malang. Dalam penelitian ini, telah dilakukan wawancara terhadap 15 orang yang mewakili berbagai kelompok, institusi, maupun perorangan di wilayah Kota Malang. Para narasumber tersebut dapat dikelompokkan menjadi: (a) kelompok pemilik bangunan yang bersifat milik pribadi (pemilik rumah sebagai tempat tinggal) maupun fasilitas umum; (b) kelompok akademisi yang terdiri atas dosen dan guru SMA; (c) kelompok birokrasi atau pemerintah; (d) kelompok LSM (Lembaga Swadaya Masyarakat); dan (e) kelompok pengusaha yang terdiri atas pengelola restoran, hotel, dan biro perjalanan wisata. Wawancara yang dilakukan bersifat tertutup, dengan berpedoman pada pertanyaanpertanyaan yang telah disusun sebelumnya.

Selain identitas, ada beberapa pokok materi pertanyaan yang diajukan kepada para nara sumber. Pertama sejauhmana pemahaman para narasumber terhadap apa yang disebut dengan bangunan indis beserta makna apa yang terkandung di dalamnya. Kedua apa pendapat mereka berkaitan dengan pemanfaatan bangunan indis, sebagai salah satu dari bentuk kegiatan pengelolaan $\mathrm{BCB}$. Ketiga apa yang mereka ketahui tentang kegiatan penyebarluasan informasi tentang bangunan indis di Kota Malang 
dewasa ini. Kesemua pertanyaan itu menyangkut kondisi yang ada sekarang maupun harapan mereka yang belum dilaksanakan.

\section{HASIL SURVEI}

Dari hasil kegiatan wawancara dapat diketahui bahwa sebagian besar narasumber pada umumnya mengerti dan memahami apa yang disebut dengan bangunan indis, meskipun kadar pemahamannya tidak sama. Secara umum bangunan indis memang sangat berbeda dengan bangunan asli atau bangunan tradisional setempat. Bangunan indis mempunyai ciri yang sangat khusus dan menonjol yaitu bangunannya relatif tinggi, dengan ventilasi, pintu, dan jendela yang cukup besar. Bentuk yang demikian ini dimaksudkan agar sirkulasi udara yang keluar masuk bangunan tetap enak, segar, bebas, dan bersih.

Terkait dengan pemanfaatan bangunan indis, umumnya disebutkan kegiatan ini harus diawali dengan pelestarian. Cara pemanfaatan bangunan indis yang dikemukakan adalah dikaitkan dengan kepentingan dunia pendidikan. Dalam hal ini bangunan indis dapat dijadikan sebagai sarana pembelajaran pendidikan sejarah dalam rangka mengenang perjuangan rakyat Indonesia, khususnya perlawanan penduduk Kota Malang terhadap pengaruh asing. Untuk itu pengetahuan tentang bangunan indis dapat dijadikan sebagai muatan lokal dalam kurikulum sekolah. Bangunan tersebut harus ditempatkan sebagai sumber pengetahuan dan pencitraan jati diri budaya bangsa. Untuk memperoleh pemahaman yang lebih mendalam, anak-anak sekolah perlu diajak langsung mengunjungi bangunan indis di Kota Malang, di samping kunjungan ke museum dan situs-situs lain.

\section{Pemanfaatan}

bangunan indis lainnya adalah untuk bahan kajian di dunia penelitian. Sesungguhnya pemanfaatan bangunan indis di Kota Malang untuk penelitian hingga saat ini sudah banyak dilakukan, namun hasil penelitian belum diikuti dengan tindak lanjut yang nyata. Berbagai penelitian yang pernah dilakukan terkait dengan bangunan indis adalah penelitian Gaya

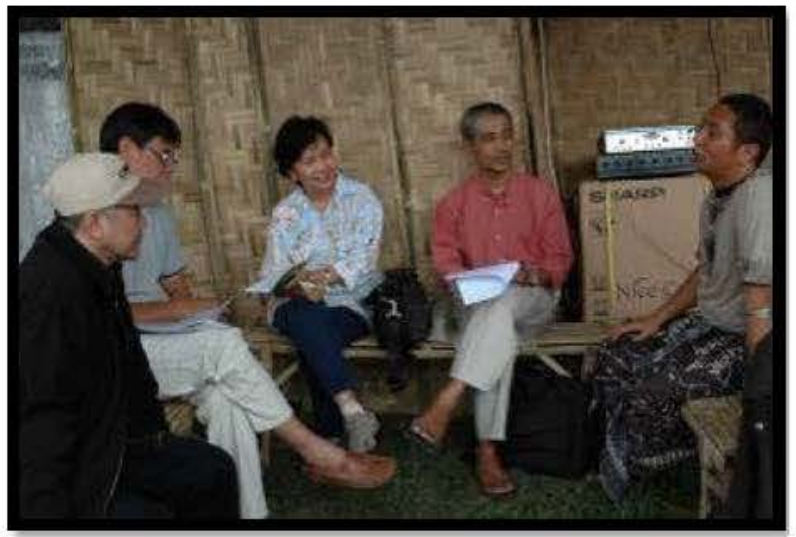

Wawancara dengan Dwi Cahyono selaku ketua dan pemilik Yayasan Inggil

Dan Fungsi Ornamen Pada Bangunan Hotel Niagara Di Lawang: Kajian Sejarah Kebudayaan (Rindhowati, 2003), penelitian Perkembangan Kota Malang 1914 - 1942: Kajian Atas Intervensi Pemerintahan Kolonial Hindia 
Belanda (Kurniawan, 2006), dan penelitian Pemanfaatan Bangunanbangunan Kolonial Belanda Di Kota Malang Pasca 1950 (Pinardi, 2007), serta Studi Penentuan Kriteria Bangunan Untuk Perlindungan Dan Pelestarian Bangunan Bersejarah Di Kota Malang Sebagai Dasar Penerbitan Perijinan (Anonim, 2003). Meskipun demikian ada juga responden yang mengatakan bahwa tidak semua bangunan kuna dapat dijadikan sebagai objek penelitian, seperti bangunan tempat tinggal karena tidak ada sejarahnya.

Pemanfaatan lainnya dapat dilihat dari sudut pandang ekonomi. Menurut sudut pandang bidang ini, pemanfaatan bangunan indis terutama untuk bidang kepariwisataan melalui wisata minat khusus. Salah satunya adalah wisata kuliner. Kegiatan wisata kuliner ini secara tidak langsung sudah dapat dilihat contohnya di Kota Malang dalam kasus pemanfaatan Toko OEN. Toko ini di masa lalu merupakan toko makanan. Meskipun demikian wisata jenis ini di Kota Malang belum sepenuhnya dapat dikembangkan dan perlu dikemas dengan menambahkan kegiatan lain sebagai pendukung, misalnya dibuatkannya atraksi tertentu. Wisata jenis lain yang dapat dikembangkan adalah wisata nostalgia. Sasaran wisata ini terutama adalah generasi tua yang ingin mengenang kembali masa lampau dengan melihat suasana dan bangunan tinggalan masa lampau.

Pemikiran tentang berbagai kegiatan seperti tersebut di atas akan dapat diketahui oleh masyarakat luas jika informasi yang ada dapat disebarluaskan secara kontinyu. Sebagian besar responden menilai bahwa berbagai informasi tentang bangunan indis di Kota Malang hingga saat ini masih sangat kurang disebarluaskan. Hal ini terlihat dengan banyaknya warga yang membangun bangunan baru tanpa memperhatikan bangunan lama dan cenderung melupakan sejarah masa lalu. Penyebarluasan informasi yang ada selama ini masih terbatas pada tingkat antar individu dan belum menjadi kegiatan publik yang lebih luas. Meskipun ada pula sebagian responden yang mengatakan bahwa informasi tentang bangunan indis di Kota Malang hingga saat ini sudah dapat dianggap cukup, meskipun dengan catatan akan lebih bagus jika ada peningkatan. Pemyataan ini didukung dengan adanya kegiatan Festival Malang Kembali. Dalam kegiatan itu dipublikasikan juga keberadaan bangunan kuna (antara lain bangunan indis dan candi), makanan tradisional, permainan tradisional, hingga pakaian tradisional. Dalam kaitan dengan ini, dapat disarankan agar diselenggarakan berbagai kegiatan pengenalan bangunan indis dengan melibatkan generasi muda, antara lain berupa pameran, kunjungan ke objek, dan pembuatan film dokumenter. Di samping itu diusulkan pula pembuatan dan pemasangan baliho, plakat-plakat, peta atau denah objek, dibuatkan arah penunjuk jalan ketempat-tempat wisata, dan nama-nama jalan lama sebaiknya dicantumkan di bawah nama jalan yang baru. Untuk itu perlu adanya program yang konkrit dan sinergis serta terkoordinasi dari berbagai pihak yang terlibat dalam melestarikan bangunan indis untuk disebarluaskan informasinya kepada masyarakat luas. 
Dalam meningkatkan promosi dan pengenalan tentang bangunan indis penting pula dilakukan kerjasama dengan berbagai pihak. Biro perjalanan dapat membantu penyebarluasan informasi ini kepada para calon dan pengunjung Kota Malang. Peranan stasiun televisi setempat penting pula dalam rangka penyebarluasan informasi seperti ini. Yang tidak kalah pentingnya adalah melalui jalur sekolah perlu dikembangkan museum lokal dan untuk umum dapat diciptakan peta tematik bangunan indis. Dalam era globalisasi sekarang ini pembuatan website sangat mendukung kegiatan publikasi. Semua itu perlu mendapat dukungan pihak legislatif dan eksekutif yang ada di Kota Malang.

\section{BEBERAPA JENIS KEGIATAN PEMANFAATAN}

Pemanfaatan sumberdaya arkeologi (SDA) atau Benda Cagar Budaya $(B C B)$ merupakan salah satu kegiatan dari pengelolaan. Memanfaatkan kembali sumberdaya arkeologi sesungguhnya sama pentingnya dan harus sejalan dengan upaya untuk melestarikannya. Pemanfaatan BCB telah diatur dalam Undang-undang Republik Indonesia (UURI) No. 5 Tahun 1992 tentang BCB yaitu pada bab VI, pasal 19, ayat 1 dan Peraturan Pemerintah Republik Indonesia (PPRI) No. 10 Tahun 1993 tentang Pelaksanaan UURI No. 5 Tahun 1992. Di dalam kedua perangkat hukum tersebut disebutkan BCB dapat dimanfaatkan untuk kepentingan agama, sosial, pariwisata, pendidikan, ilmu pengetahuan, dan kebudayaan. Dari dasar hukum tersebut, secara operasional pemanfaatan $B C B$ dapat diringkas menjadi empat, yaitu: agama, sosial dan pariwisata, pendidikan dan ilmu pengetahuan, serta kebudayaan. Bentuk-bentuk pemanfaatan seperti itu temyata telah diterapkan pada bangunan indis di Kota Malang. Berikut ini akan diberikan beberapa contoh dari bentuk-bentuk pemanfaatan tersebut.

\section{Pemanfaatan Untuk Agama}

Ada empat bangunan indis di Kota Malang yang pemanfaatannya berkaitan dengan bidang agama, terutama untuk peribadatan. Keempat bangunan itu adalah : Gereja Protestan Indonesia Barat (GPIB) yang terletak di Jl. Merdeka Barat No. 1; Gereja Katholik Hati Kudus yang terletak di Jl. MGR. Sugiyopranoto No. 2; Gereja Katolik Katedral atau Gereja Kathedraal yang terletak di Jl. Buring No. 60; dan Gereja Kalam Kudus yang terletak di Jl. Semeru No. 30. Dari sisi pengetahuan sejarah, pemanfaatan bangunan-bangunan dapat dijelaskan dalam konteks sejarah masuk dan berkembangnya pengaruh agama Kristen Protestan dan Katolik di Indonesia. Agama yang dibawa oleh orang Eropa (khususnya Belanda) ini memiliki pengaruh yang cukup besar pada perkembangan budaya di kota ini. 


\section{Pemanfaatan Untuk Sosial dan Pariwisata}

Pemanfaatan BCB untuk kepentingan sosial dan pariwisata dapat diwujudkan dengan memanfaatkan bangunan indis di Kota Malang sebagai ciri suatu kawasan tertentu. Keberadaan bangunan-bangunan tersebut akan memberikan suasana khas pada kawasan tersebut, sehingga perjalanan sejarah perkembangan kota masih dapat dirasakan. Bangunan yang memiliki ciri-ciri yang khas itu, akan dapat menjadi tetenger atau landmark Kota Malang.

Bangunan-bangunan kuna yang ada di Kota Malang merupakan living monument yang secara syah dimiliki masyarakat, pemerintah, maupun kelompok masyarakat atau golongan tertentu. Oleh karena itu, mereka selaku pemilik bangunan perlu pemahaman yang cukup agar kelestariannya dapat lebih terjaga. Pengelolaan terhadap bangunan tersebut amat penting, sebab pemilik bangunan merupakan ujung tombak pelestarian dan pemanfaatan suatu BCB. Dengan pemahaman yang meningkat, partisipasi pemilik bangunan diharapkan dapat terlibat dan melibatkan diri dalam manajemen pengelolaan warisan budaya mulai dari perencanaan, pelaksanaan, monitoring, hingga evaluasi.

Selain itu, bangunan-bangunan indis di Kota Malang dapat difungsikan sebagai objek dan daya tarik wisata (ODTW). Dalam hal ini ada saling ketergantungan yang sangat erat antara pariwisata dengan bangunan sebagai sumberdaya arkeologi. BCB tersebut dapat menjadi dan sekaligus menciptakan daya tarik yang akan meningkatkan pertumbuhan pariwisata. Di sisi yang lain, semestinya kegiatan pariwisata akan mampu menciptakan dana untuk melestarikan BCB. BCB yang lestari akan dapat dimanfaatkan sebagai modal pariwisata untuk jangka waktu yang lama.

Sumberdaya budaya berupa bangunan kuna akan sangat berkurang nilainya tanpa ada tanggungjawab dari wisatawan dan pemilik bangunan yang aktif dalam memanfaatkannya. Optimalisasi nilai $B C B$ dapat memberikan kontribusi peningkatan kualitas hidup pemilik bangunan. Namun keuntungan jangka pendek dan kepentingan kelompok tertentu seringkali menyebabkan degradasi atau penurunan kualitas bahkan musnahnya BCB dimaksud. Jika hal tersebut dapat diatasi, masyarakat akan mendapatkan pengalaman berkebudayaan, baik bagi kepentingan generasi sekarang sampai generasi

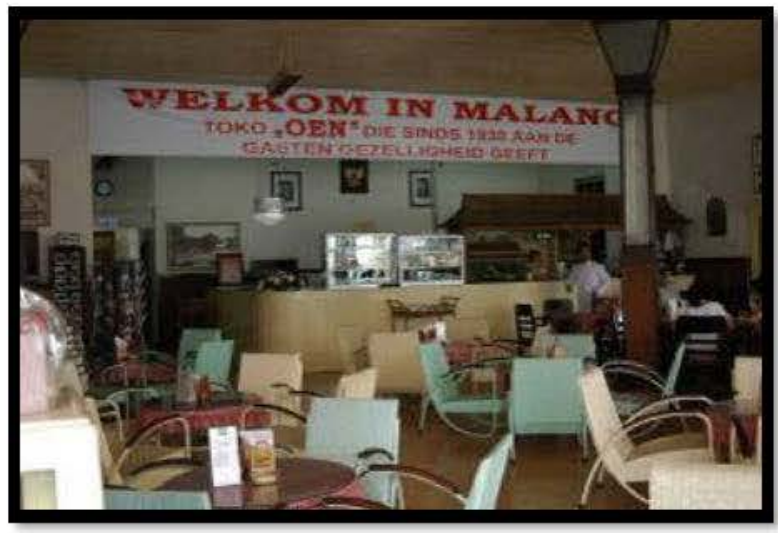

Keadaan di dalam Toko OEN dengan masih mempertahankan perabot meja-kursi khas masa lalu yang akan datang (Soeroso, 2007: 2 - 3). 
Realisasi hubungan antara bangunan indis di Kota Malang dengan kepariwisataan dapat diberikan contoh sebagai berikut. Bangunan indis di Kota Malang, khususnya yang dahulu hingga sekarang sebagai Toko OEN dapat dijadikan sebagai objek wisata minat khusus yang terkait wisata kuliner. Wisata minat khusus merupakan jenis kepariwisataan yang mempunyai tiga ciri. Pertama, wisatawan yang datang jumlahnya terbatas dan cenderung sangat sedikit. Kedua, untuk mengikuti wisata jenis ini memerlukan biaya yang rata-rata lebih mahal dibanding dengan jenis wisata lain. Ketiga, wisatawan cenderung untuk mencari bentuk wisata yang berorientasi pada pengalaman dan manfaatnya dapat bertahan lama (Chawari, 2007a: 263 - 277). Dengan demikian ketiga ciri tersebut dapat direalisasikan oleh Toko OEN yang merupakan toko makanan sebagai tempat wisata minat khusus, khususnya wisata kuliner.

\section{Pemanfaatan Untuk Pendidikan dan IImu Pengetahuan}

Pemanfaatan $\mathrm{BCB}$ dapat juga dikaitkan dengan pendidikan dan ilmu pengetahuan. Dalam hal ini BCB dapat dijadikan sebagai media pendidikan. Dalam posisi yang demikian ini, bangunan indis di Kota Malang dapat dikatakan sebagai salah satu identitas kota tersebut. Identitas budaya tersebut dapat diwariskan dari suatu generasi ke generasi berikutnya

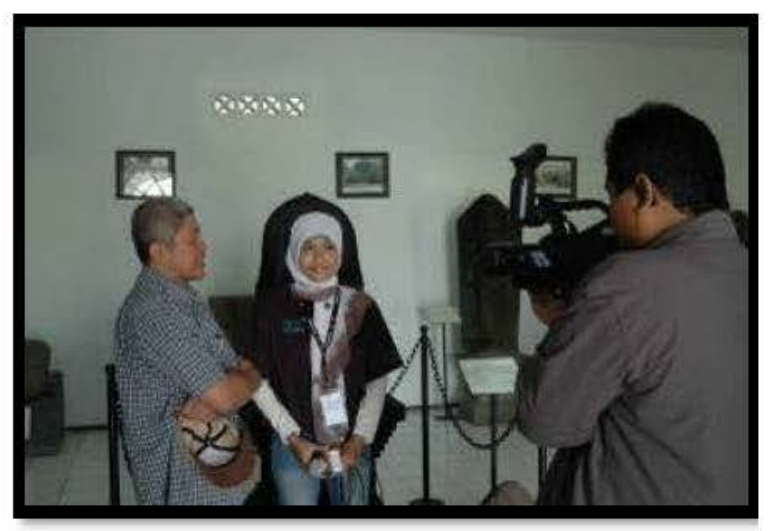

Proses pengambilan gambar dalam acara salah satu stasiun TV, dinilai lebih efektif

melalui aktivitas pendidikan.

Dalam kegiatan seperti inilah $\mathrm{BCB}$ dapat berperan dan berfungsi sebagai sarana pewarisan generasi tua ke generasi muda. Kunjungan ke museum ataupun ke situs arkeologi tertentu dapat juga dikatakan berhasil menanamkan pemahamanpemahaman kesejarahan pada siswa-siswa sekolah yang dapat dimulai sejak usia dini (Cleere, 1989: 9). Melalui pemahaman akan keberadaan bangunan Indis kepada siswa dapat ditanamkan pengertian bahwa di Indonesia terdapat budaya asing, salah satunya budaya yang terpengaruh Belanda. Budaya asing tersebut memiliki ciri tertentu yang kemudian disesuaikan dengan kondisi di Indonesia, sehingga memperkaya budaya Indonesia, khususnya dalam bidang arsitektur. Selain itu, dapat saja para siswa diberikan penjelasan lebih jauh hal-hal yang berhubungan dengan arsitektur bangunan indis tersebut beserta filosofi yang melatarbelakangi didirikannya bangunan tersebut. Dalam kenyataannya pemanfaatan untuk pendidikan dan ilmu pengetahuan tersebut masih sangat sulit dilaksanakan. Untuk itu perlu diupayakan agar dapat menjadi 
bahan pengajaran yang komunikatif. Inilah yang hingga saat ini belum dapat diwujudkan secara menyeluruh.

Keberadaan bangunan-bangunan indis dapat dikaitkan dengan sejarah tumbuh dan berkembangnya Kota Malang, bahkan dapat juga dikaitkan dengan perjuangan dan perlawanan masyarakat Malang terhadap pengaruh asing (Belanda). Kesemuanya itu dapat dijadikan sebagai bahan pengajaran pada jenjang pendidikan formal tertentu di daerah Malang dan sekitarnya. Jenjang pendidikan yang dimaksud mulai dari tingkat dasar (TK) sampai dengan tingkat (SLTA) bahkan perguruan tinggi yaitu sebagai muatan lokal (mulok). Selain sebagai muatan lokal, keberadaan bangunanbangunan tersebut dapat juga digunakan sebagai bahan pengajaran pada jenjang pendidikan non-formal maupun informal. Kegiatan pada jenjang ini misalnya melalui kegiatan pada Program Bimbingan Belajar, kegiatan Pramuka, Karang Taruna dll.

\section{Pemanfaatan Untuk Kebudayaan}

Bangunan indis di Kota Malang khususnya dan di Indonesia pada umumnya merupakan wujud budaya fisik yang berasal dari pengaruh Eropa, terutama Belanda. Namun demikian bukan berarti bahwa bangunanbangunan tersebut harus dihancurkan dan dibongkar serta diganti dengan bangunan baru dengan alasan tidak cocok dengan budaya asli bangsa Indonesia. Justru bahwa bangunan-bangunan tersebut dapat dijadikan sebagai bagian dari sejarah terbentuknya Kota Malang pada waktu itu, mengingat bahwa pada awalnya Malang tidak berdiri sendiri, tetapi merupakan bagian dari suatu kawasan yang cukup luas yaitu bagian dari Karesidenan Pasuruan. Tidak hanya sampai di situ saja, pemanfaatan lain bangunan indis dengan unsur-unsur budaya asing tersebut adalah sebagai pembanding antara arsitektur lokal dengan arsitektur asing. Kesemuanya itu akan bermanfaat bagi pembangunan fisik di Kota Malang dewasa ini dan yang akan datang. Sementara itu, dengan belajar dari kebudayaan masa lampau dimungkinkan manusia yang hidup pada era globalisasi ini dapat menghindarkan diri dari kesalahan-kesalahan yang pernah terjadi di masa lampau.

Beberapa bentuk pemanfaatan seperti tersebut di atas merupakan pemanfaatan yang bersifat teoritis atau idealis. Agar jenis pemanfaatan yang demikian ini dapat operasional dan diaplikasikan sesuai dengan bidangnya, maka harus diawali dengan kajian atau studi. Studi ini merupakan kegiatan pendahuluan dalam merencanakan pemanfaatan BCB agar sesuai dengan keadaan dan tuntutan masa sekarang dan masa yang akan datang.

Selain pemanfaatan seperti telah diuraikan di atas, yaitu berdasarkan atas amanat UURI No. 5 Tahun 1992 dan PPRI No. 10 Tahun 1993, di Kota Malang bangunan indis yang ada telah dimanfaatkan untuk menunjuk kegiatan dan event-event yang diselenggarakan di kota ini. 


\section{Festival Malang Kembali}

Festival Malang Kembali atau Malang Old Festival merupakan suatu kegiatan yang diadakan atas kerjasama antara Pemda Kota Malang dengan Yayasan Inggil, Telkomsel, dan Harian Radar Malang. Kegiatan pada tahun 2008 merupakan yang ke-3 karena kegiatan ini dimulai sejak tahun 2006. Tahun 2008 Festival Malang Kembali dilaksanakan selama empat hari yaitu mulai tanggal 22 - 25 Mei 2008 dan bertempat di Kawasan Jl. Ijen (Radar Malang, Kamis, 22 Mei 2008. Hal: 3 - 4). Dalam kenyataannya kegiatan tersebut tidak hanya menampilkan posisi Malang dalam kerangka kronologi masa kolonial saja, tetapi dimulai dari jaman prasejarah. Hal ini dapat dilihat dari poster dan baliho berukuran besar yang menampilkan beberapa candi yang ditemukan di sekitar Malang.

Festival Malang

Kembali tahun 2008 dengan motto Satu Aksi Sejuta Tradisi. Dalam kegiatan tersebut ditampilkan fragmen perjalanan sejarah kuna Malang secara detail dimulai dari munculnya dataran tinggi Malang dan perjalanan jaman prasejarah hingga terbentuknya Kerajaan Majapahit. Selain itu, melalui layar lebar disampaikan juga pengetahuan baru tentang posisi Malang dalam kancah

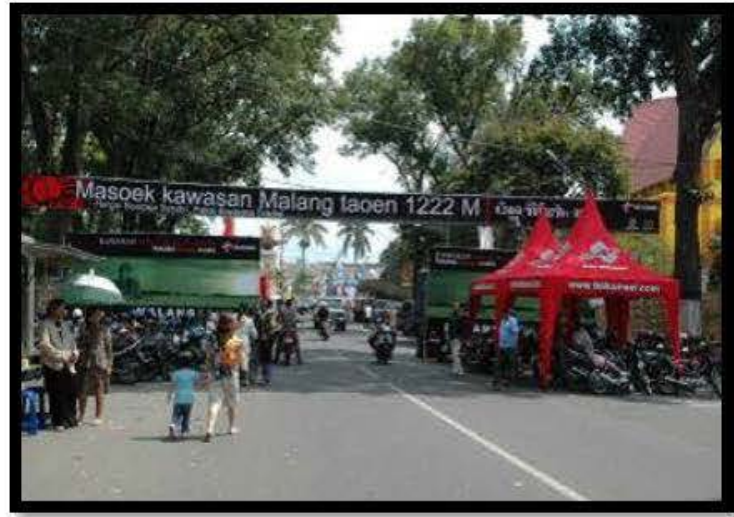

Salah satu dari beberapa pintu gerbang masuk ke lokasi Festival Malang Kembali tahun 2008

kenegaraan. Majapahit merupakan kerajaan besar yang cikal bakalnya dimulai dari Malang,

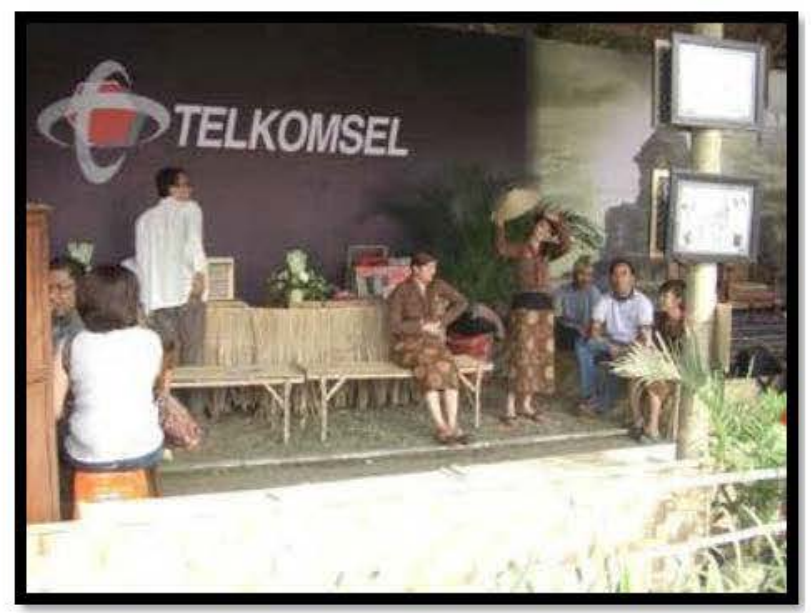

Kegiatan Festival Malang Kembali

bekerjasama dengan salah satu pengelola jaringan telpon dinilai sangat menguntungkan sehingga kota ini mempunyai peran penting dalam berdirinya negara Indonesia. Kegiatan semacam ini diharapkan dapat menjadi salah satu agenda wisata bagi masyarakat Malang dan sekitarnya. Dalam acara tersebut masing-masing stan menampilkan berbagai kegiatan antara lain: kegiatan membatik, membuat keramik, membuat topeng, laras gamelan, pameran artefak, pandai besi, 
jamasan keris, pahat batu, praktek menulis dalam daun lontar, panggung ludruk, musik keroncong, musik gambus dll (Radar Malang, Jum'at, 23 Mei 2008. Hal: 29 dan 43).

Jika dilihat secara seksama kegiatan ini diilhami pula atas adanya berbagai keprihatinan. Salah satunya adalah posisi pendidikan seni dan budaya di sekolah sangat memprihatinkan. Hal ini dapat dilihat dari posisi pendidikan jenis ini dibandingkan dengan mata pelajaran sains dan teknologi. Padahal pendidikan seni dan budaya merupakan simbol kebanggaan, keluhuran, dan harga diri bangsa. Kondisi ini akan berdampak pada kehidupan berbangsa. Dampak yang paling jelas adalah masyarakat merasa asing terhadap kebudayaannya sendiri (Radar Malang, Kamis, 22 Mei 2008. Hal: 41).

Dalam acara ini Telkomsel mengadakan lomba permainan tradisional yang meliputi: permainan egrang, gobagsodor, bola bakar (bola api), dan engklek yang dapat diikuti oleh seluruh lapisan masyarakat Kota Malang (Radar Malang, Jum'at, 23 Mei 2008. Hal: 33). Dengan adanya festival ini diharapkan bahwa para siswa sekolah dapat belajar sejarah kota Malang dan kebudayaan lokal (Radar Malang, Sabtu, 24 Mei 2008. Hal: 29 dan 43). Selanjutnya dalam penutupan Festival Malang Kembali yang dilaksanakan pada tanggal 25 Mei 2008 ditampilkan berbagai acara, salah satunya adalah ruwatan akbar. Upacara semacam ini di Jawa telah berlangsung bertahun-tahun. Dalam ruwatan tersebut ditampilkan juga pagelaran wayang, potong rambut, pemberian tumpeng, dan pelepasan burung dara (Radar Malang, Senin, 26 Mei 2008. Hal: 33).

\section{Pemanfaatan lain}

Bentuk lain pemanfaatan bangunan indis adalah berkaitan dengan dijadikannya objek tersebut sebagai inspirasi barang jualan (merchandise) berupa pola hiasan yang ditempel pada kaos dengan cara disablon maupun dibuat stiker. Pada kegiatan Festival Malang Kembali tahun 2008 yang lalu

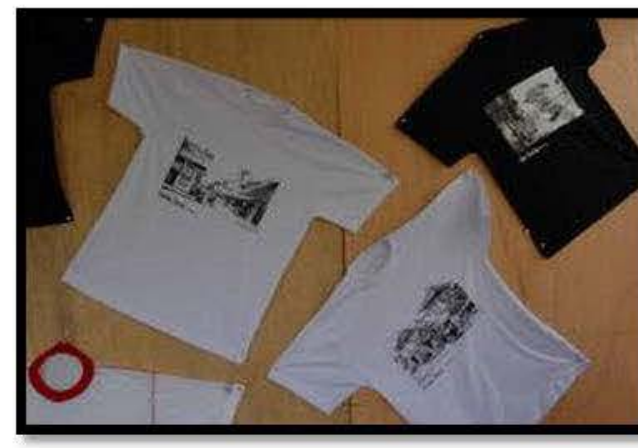

Berbagai bangunan índís menghiasai kaos yang dijual di arena Festival Malang Kembali

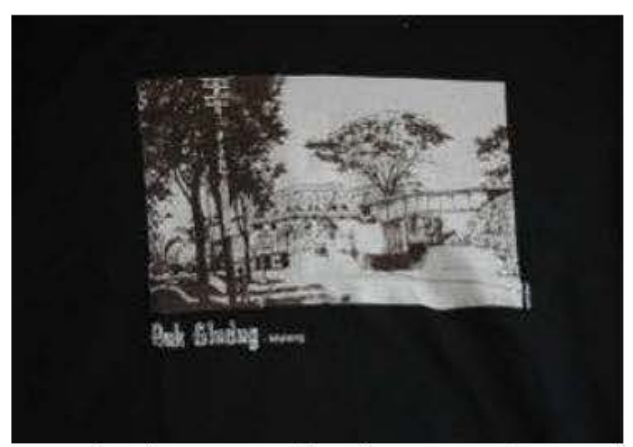

Jembatanpun ikut berperan juga menghiasi kaos yang dijual

banyak kaos dalam berbagai ukuran yang dijual dengan diberi hiasan jenisjenis bangunan indis yang banyak terdapat di Kota Malang. Bangunan- 
bangunan yang dijadikan sebagai hiasan dan daya tarik kaos antara lain: pintu gerbang pasar, Toko OEN, bangunan sociteit (kamar bola), Hotel Pelangi, jembatan, salah satu sudut kota yang berfungsi sebagai toko di Malang kuna, jam kuna di tengah jalan, rel kereta api (trem), berbagai jenis angkutan masa lalu yang pernah beroperasi di Malang dll.

Selain itu, melalui media foto bangunan tersebut ditempel pada dinding rumah. Hal ini antara lain telah dilakukan oleh Rumah Makan Inggil dan Toko OEN. Rumah Makan Inggil yang terletak di Jl. Gajah Mada No. 4 telah memajang foto-foto kuna dari berbagai bentuk bangunan indis yang ada di kota ini. Di samping foto, dipajang pula radio kuna, mesin jahit, seterika, mesin ketik dan beberapa benda kuno lainnya yang semuanya berasal dari Malang dan sekitarnya. Sementara itu, Toko OEN yang terletak di Jl. Basuki Rahmad No. 5 (dahulu Jl. Kajoetangan) juga memajang berbagai foto-foto kuna bangunan-bangunan indis. Seperti tidak mau ketinggalan, toko roti dan oleh-oleh makanan khas Malang

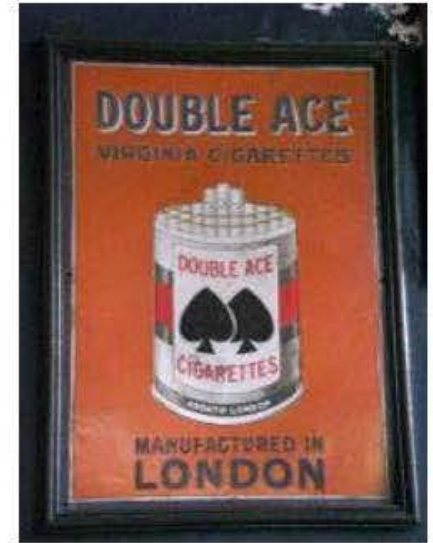

Salah satu contoh iklan lama yang masih digemari para pengelola bangunan kuna

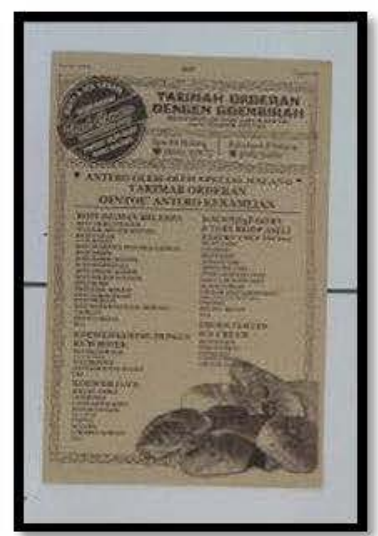

Salah satu bentuk iklan makanan yang dibuat dengan kesan kuna

yaitu Toko UND CORNER yang terletak di Jl. Kahuripan No. 3 juga menampilkan nuansa Malang Kuna. Toko tersebut tidak memajang foto-foto kuna, tetapi memajang berbagai bentuk iklan (advertensi) jaman kuna. Berbagai bentuk iklan yang pernah beredar di daerah Malang sekitar awal hingga pertengahan abad XX ditampilkan atau dipajang pada dinding toko, antara lain iklan produk minuman, rokok, sampo, sarung dan kain, serta iklan berbagai toko. Toko tersebut pada tahun 2008 juga membuat iklan dengan bentuk dan format yang memberikan kesan iklan kelihatan lama. Iklan ini memuat informasi berbagai makanan yang diproduksi dan dijual di toko tersebut. Iklan berupa selebaran ini dibagikan kepada para konsumen.

\section{PENUTUP}

Berbagai bentuk pemanfaatan bangunan indis di Kota Malang yang merupakan salah satu bentuk sumberdaya arkeologi (SDA) dapat dilihat sebagai salah satu kegiatan pengelolaan dan sekaligus pelestarian. Dari hasil pengamatan dapat diidentifikasikan beberapa bentuk pemanfaatan. 
Secara umum pemanfaatan itu dapat dikelompokkan menjadi dua berdasarkan sifatnya, sebagai berikut.

a. Pemanfaatan yang bersifat teoritis atau idealis yaitu pemanfaatan yang didasarkan atas UURI No. 5 Tahun 1992 tentang BCB. Bentuk-bentuk pemanfaatan yang dimaksud dikaitkan dengan kepentingan agama, sosial, pariwisata, pendidikan, ilmu pengetahuan, dan kebudayaan. Secara umum pemanfaatan seperti ini belum sepenuhnya mendapat perhatian dan menjadi kebijakan dari Pemda setempat. Pemanfaatan seperti ini masih bersifat individual dan terkesan sepotong-sepotong.

b. Pemanfaatan yang bersifat praktis adalah pemanfaatan yang bernuansa ekonomis. Pemanfaatan yang demikian pada umumnya sudah dilaksanakan, namun pelaksanaannya lebih bersifat individual dan belum sampai pada tataran instansional. Kegiatan praktis yang dimaksud diwujudkan melalui berbagai bentuk kegiatan, antara lain :

- Kegiatan Festival Malang Kembali atau Malang Old Festival.

- Pembuatan kaos dan stiker dengan gambar bangunan indis.

- Foto-foto bangunan indis dipajang di beberapa bangunan kuno yaitu restoran, hotel, dan toko.

- Nuansa Malang tempo dulu juga diperlihatkan oleh salah satu toko roti khas Malang dengan menampilkan berbagai bentuk iklan (advertensi) jaman dulu.

\section{KEPUSTAKAAN}

Anonim. 2003. Studi Penentuan Kriteria Bangunan Untuk Perlindungan Dan Pelestarian Bangunan Bersejarah Di Kota Malang Sebagai Dasar Penerbitan Perijinan (Laporan Akhir). Malang: Kerjasama Antara Pemerintah Kota Malang dengan Fakultas Teknik Universitas Brawijaya.

Chawari, Muhammad. 2007. Laporan Penelitian Arkeologi Bangunan Indis di Kotamadia Malang: Identifikasi Potensi dan Perencanaan Pengembangannya (Tahap I). Yogyakarta: Balai Arkeologi.

. 2007a. "Kompleks Pesanggrahan Tamansari Yogyakarta: Manfaat Seni Hias dalam Konteks Pengembangannya", dalam Inajati Adrisijanti dan Musadad (ed.) Knyamika: Melacak Akar dan Perkembangan Kriya. Yogyakarta: Penerbit Jurusan Arkeologi, Fakultas IImu Budaya, Universitas Gadjah Mada, hal: 263 - 277

Cleere, H.F. 1989. Introduction: The Rationale of Archaeological Heritage Management, dalam Cleere, H.F (ed.) Archaeological Heritage Management in the Modern World. London: Unwin Hyman, halaman: $1-19$. 
Kurniawan, Jujun. 2006. Perkembangan Kota Malang 1914 - 1942: Kajian Atas Intervensi Pemerintahan Kolonial Hindia Belanda. Yogyakarta: Skripsi Sarjana pada Jurusan Arkeologi, Fakultas IImu Budaya, Universitas Gadjah Mada.

Peraturan Pemerintah Republik Indonesia No. 10 Tahun 1993 tentang Pelaksanaan Undang-undang No. 5 Tahun 1992.

Pinardi, Slamet. 2007. Pemanfaatan Bangunan-bangunan Kolonial Belanda Di Kota Malang Pasca 1950. Yogyakarta: Tesis Master pada Jurusan Arkeologi, Fakultas IImu Budaya, Universitas Gadjah Mada.

Rindhowati, Aris. 2003. Gaya Dan Fungsi Ornamen Pada Bangunan Hotel Niagara Di Lawang. Malang: Skripsi Sarjana pada Jurusan Sejarah, Fakultas Sastra, Universitas Negeri Malang.

Soeroso, Amiluhur. 2007. Penilaian Kawasan Pusaka Borobudur Dalam Kerangka Perspektif Multiatribut Ekonomi Lingkungan Dan Implikasinya Terhadap Kebijakan Manajemen Ekowisata. Yogyakarta: Disertasi dalam IImu Lingkungan pada Universitas Gadjah Mada.

Undang-undang Republik Indonesia Nomor 5 Tahun 1992 tentang Benda Cagar Budaya (BCB).

\section{HARIAN}

Radar Malang, Kamis, 22 Mei 2008. Hal: 3 - 4, "Jalan ljen Ditutup Total: Ajang Malang Kembali".

Radar Malang, Kamis, 22 Mei 2008. Hal: 41, "Mata Pelajaran Seni Budaya Tersingkir".

Radar Malang, Jum'at, 23 Mei 2008. Hal: 29 dan 43, "Sejarah Malang Buka FMK".

Radar Malang, Jum'at, 23 Mei 2008. Hal: 33, "Griya Telkomsel Diserbu".

Radar Malang, Sabtu, 24 Mei 2008. Hal: 29 dan 43, "Bule Pun Main Egrang"

Radar Malang, Senin, 26 Mei 2008. Hal: 33, "Ditutup, Panitia Klaim Dikunjungi Sejuta Orang". 